\title{
PERSPEKTIF HUKUM ISLAM TENTANG SENI
}

\section{Darmiko Suhendra \\ STAIN Syaikh Abdurrahman Siddik Bangka Belitung}

\begin{abstract}
Art is defined as the expertise to disclose or express ideas and thoughts a esthetics, including the ability and imagination to realize the creation of objects or the work atmosphere capable of inflicting a sense beautiful. Art is diverse and most of it always questionable in terms of Islamic law. In general, the art divided into two: first, sculpture, painting and drawing. And second, sound art. The main problem in sculpture, painting and drawing is if the object of animate beings, because on the one hand there are numbers of hadith that prohibit making images that are either raised or incurred and three dimensions. While on the other hand it has been commonly done in the community, especially in the natural environment that is fertile and rich with a variety of animals created by God as our State that inspired the artists. In addition, the sculpture on the side can be an expression of sheer beauty, it also has benefits for lessons and so on. Furthermore, sound art is a universal cultural phenomenon, practiced by many nations. In the time of the Prophet himself has been known to sing and play music. In terms of general principles of religious teachings that sound art including mu'amalat dunyawiyyah category. Restrictions on the arts (sculpture, painting, drawing, and sound) for their prudence of Muslims. Prudence was intended that they do not fall to the things that are contrary to the values of Islam which is the focal point at that time. Art as an aesthetic manifestation of the spirit of monotheism and not a waste of money but the art necessary for the improvement of human life, promotion of the dignity and the dignity and refining the soul and the mind. If so the purpose of art, then it is possible that the skill and sunnah favor, not against it.
\end{abstract}

\section{Keywords: Art, Mu'amalat dunyawiyyah, Esthetics.}




\section{A. Pendahuluan}

Berbicara tentang seni, maka yang terlebih dahulu dibicarakan adalah keindahan. Sudah menjadi fitrahnya manusia menyukai keindahan. Seorang ibu akan lebih berbahagia apabila ia dikaruniai anak yang indah fisiknya, baik rupa ataupun jasmaninya. Seseorang akan lebih memilih rumah yang indah serta mengenakan pakaian-pakaian yang indah ketimbang semua itu dalam kondisi biasa-biasa saja ataupun buruk. Demikian halnya dengan lukisan, gambar, patung, nyanyian dan puisi, yang juga melambangkan keindahan, maka manusia pun akan menyukainya.

Manusia menyukai seni sebagai representasi dari fitrahnya mencintai keindahan. Dan tak bisa dipisahkan lagi antara kesenian dengan kehidupan manusia. Namun bagaimanakah dengan fenomena sekarang yang ternyata dalam kehidupan sehari-hari gambar-gambar seronok ataupun nyanyiannyanyian cinta yang diklaim sebagai seni oleh sebagian orang semakin marak menjadi konsumsi orang-orang bahkan anak-anak ataupun remaja? Bagaimanakah pandangan Islam (baca: hukum Islam) terhadap hal-hal tersebut?. Oleh karena itulah, dalam tulisan ini akan dibahas seni dalam tinjauan hukum Islam.

\section{B. Sekilas Tentang Seni}

Seni diartikan sebagai keahlian mengungkapkan atau mengekspresikan ide-ide dan pemikiran estetika, termasuk mewujudkan kemampuan serta imajinasi penciptaan benda-benda, suasana atau karya yang mampu menimbulkan rasa indah. ${ }^{1}$

Seni merupakan ekspresi keindahan. Dan keindahan menjadi salah satu sifat yang dilekatkan Allah pada penciptaan jagat raya ini. Allah melalui kalamnya di Al-Qur'an mengajak manusia memandang seluruh jagat raya

\footnotetext{
${ }^{1}$ Lihat Hasan Alwi, dkk., Kamus Besar Bahasa Indonesia, Jakarta: Balai Pustaka, 2005, hlm.
} 1038. 
dengan segala keserasian dan keindahannya. Allah berfirman dalam surat Qaf ayat 6, yang berbunyi:

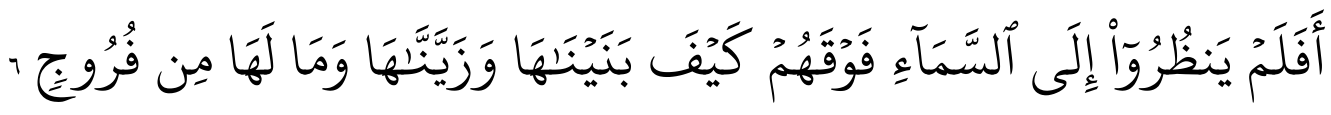

"Maka apakah mereka tidak melihat ke langit yang ada di atas mereka, bagaimana Kami meninggikannya dan menghiasinya, dan tiada baginya sedikit pun retak-retak?"

Allah juga mengajak manusia untuk melihat dari perspektif keindahan, bagaimana buah-buahan yang menggantung di pohon dan bagaimana pula buah-buahan itu dimatangkan. Jika manusia memerhatikan dan menikmati dengan pandangan yang indah, ketika arak-arakan binatang ternak saat masuk ke kandang, juga saat dilepaskan ke tempat penggembalaan, sesungguhnya pada peristiwa itu ada unsur keindahannya.

Ajakan-ajakan kepada manusia tersebut menunjukkan, pada dasarnya manusia dianugerahi Allah potensi untuk menikmati dan mengekspresikan keindahan. Seni merupakan fitrah dan naluri alami manusia. Kemampuan ini yang membedakan manusia dengan makhluk yang lain. Karena itu, mustahil bila Allah melarang manusia untuk melakukan kegiatan berkesenian.

Kalau memang demikian pandangan Islam tentang seni, mengapa pada masa awal perkembangan Islam (baca: zaman Nabi Saw dan para sahabatnya), belum tampak jelas ekspresi kaum muslim terhadap seni?. Sebagaimana diketahui bahwa pada waktu lahirnya, Islam sebagai agama sedikit sekali persentuhannya dengan seni atau kesenian. Sebab musabab keterbatasan persentuhan ini dikarenakan: ${ }^{2}$

${ }^{2}$ Al-Faruqi, The Cultural Atlas of Islam, New York: Macmilland Publishing Company, 1986, hlm. 102. 
1. Energi vital umat pada awal Islam lebih banyak tercurah pada usaha perjuangan menegakkan aqidah baru sehingga tiada sisa untuk ekspresi seni.

2. Pembentukan aqidah baru ini berakibat "pencucian" terhadap konsepkonsep, kepercayaan dan keyakinan pra-Islam itu, yang dilekati oleh semangat dan nilai-nilai jahiliyah dan karena itu sangat ditolak. Bertitik tolak dari situlah, mengapa pembuatan patung dan lukisan makhluk bernyawa, semisal: manusia dan hewan, begitu dikutuk dalam hadis-hadis Nabi. Sementara itu tradisi baru belum terbentuk untuk menjadi dasar dan sumber pengungkapan seni.

3. Dengan berubahnya masyarakat Arab pra-Islam menjadi suatu masyarakat baru dengan nilai-nilai dan pandangan hidup yang berbeda dengan sebelumnya, tujuan pengungkapan seni pra-Islam di masyarakat Arab, seperti: pujian terhadap kabilah, pembangkit semangat perang dan lainlain, kehilangan tempat dalam masyarakat Islam. Namun tujuan baru belum terkristalkan karena hal itu memerlukan pengendapan yang lama.

4. Umat Islam awal lebih banyak terpesona oleh keindahan komposisi alQur'an, sebab al-Qur'an merupakan komposisi literer terindah yang pernah dimiliki bahasa Arab sehingga mereka lebih disibukkan untuk mengapresiasi kitab dari segi ajaran dan estetikanya daripada melakukan ekspresi seni.

Kenyataan terbatasnya persentuhan Islam awal ini dengan kesenian membuat sebagian umat Islam bersikap skeptik terhadap seni dan karena itu cenderung membatasi terhadap ekspresi seni sehingga terkesan anti seni. Oleh sebab itu banyak timbul pertanyaan dalam masyarakat, bagaimana hukum seni tersebut menurut ketentuan syari'ah. Guna mengkaji masalah ini, maka dapat dilihat ke dalam dua sumber pokok hukum Islam, yakni al-Qur'an dan hadis.

Dan juga metode penemuan hukum dalam Islam tidak bersifat individualistik dan partikularistik, dalam arti bahwa apabila dihadapi suatu 
kasus, pemecahan hukumnya dilakukan dengan mencari satu atau beberapa ayat atau hadis untuk dijadikan landasan penyelesaian kasus tersebut.

Namun lebih dari itu jika berbicara tentang seni dalam pandangan hukum Islam, premis-premis hukumnya harus dicari dalam spektrum yang luas bahkan di luar hukum itu sendiri yaitu di dalam keseluruhan wawasan realitas Islam semisal pandangan tentang Tuhan, alam serta manusia dan kehidupannya.

\section{Seni dalam Pandangan Hukum Islam}

Seni memang beragam dan sebagian besar darinya selalu dipertanyakan dari segi hukum Islam. Secara umum seni terbagi dua yakni: pertama, seni patung, lukis dan gambar. Dan kedua, seni suara (baca: vokal dan instrumental).

Pertama, yakni seni patung, lukis dan gambar. Yang menjadi masalah dari seni patung, lukis dan gambar adalah apabila obyeknya makhluk bernyawa (manusia dan binatang). Permasalahanya adalah karena di satu pihak adanya sejumlah hadis yang melarang membuat gambar, baik yang tidak timbul maupun yang timbul dan tiga dimensi. Sementara di lain pihak hal tersebut telah lazim dikerjakan dalam masyarakat. Apalagi di lingkungan alam yang subur dan kaya dengan aneka ragam binatang ciptaan Tuhan seperti Negeri kita (Indonesia) yang mengilhami para seniman. Selain itu, seni patung di samping bisa menjadi ekspresi keindahan semata, juga mempunyai manfaat untuk pelajaran dan sebagainya.

Dalam al-Qur'an tidak terdapat larangan tegas membuat patung, lukisan dan gambar. Namun hanya diceritakan tindakan Nabi Ibrahim memberantas penyembahan berhala dan penghancuran terhadap berhala-berhala tersebut. ${ }^{3}$

Sedangkan dalam kitab-kitab hadis terdapat bab khusus yang memuat sejumlah hadis yang keseluruhannya melarang dengan tegas membuat dan

\footnotetext{
${ }^{3}$ Lihat Q.S al-Baqarah ayat $52-71$, dan Q.S as-Shaffat ayat 95-96.
} 
menggunakan patung dan lukisan makhluk yang bernyawa kecuali lukisan pada kain dan boneka anak-anak. Diantara hadis-hadis tersebut yakni:

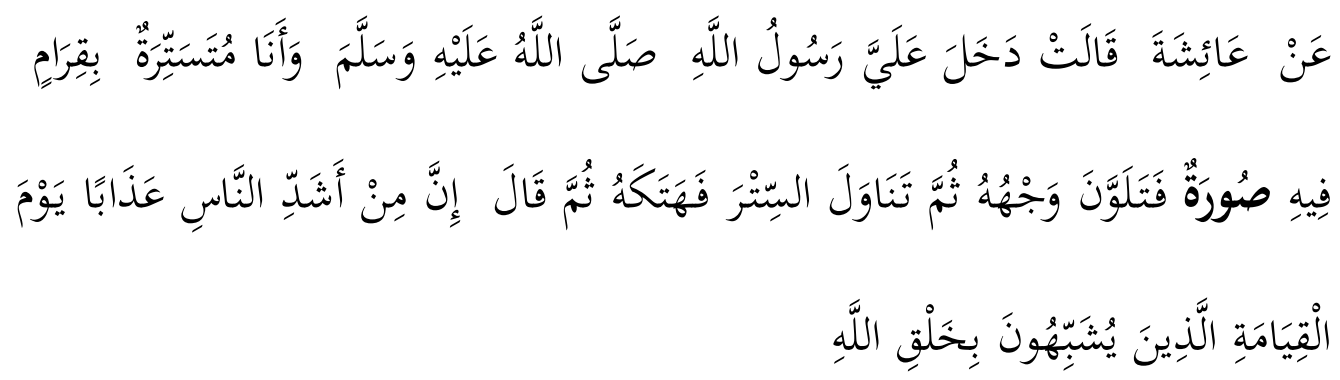

“Dari Aisyah, ia berkata: Rasulullah memergoki saya ketika saya sedang di balik sebuah tabir tipis yang padanya ada lukisan (gambar). Wajah beliau berubah warna, lalu mengambil tabir itu dan mengoyaknya. Kemudian beliau berkata: sesungguhnya orang yang paling berat siksaannya di hari kiamat adalah mereka yang meniruniru ciptaan Allah". ${ }^{4}$

Selanjutnya hadis yang menyatakan bahwa malaikat, khususnya Jibril, tidak akan masuk ke dalam rumah yang didalamnya ada suwrah (baca: patung dan lukisan) dan anjing. Hadis itu antara lain:

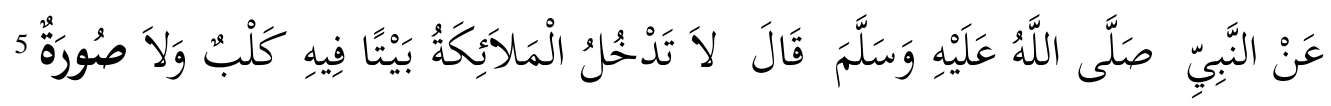

"Dari Nabi SAW bersabda: tidak akan masuk malaikat ke dalam rumah yang di dalamnya ada anjing dan suwrah (patung dan lukisan)".

Hadis-hadis tentang larangan pembuatan patung dan lukisan makhluk bernyawa ini sangat masyhur di kalangan umat Islam dan diriwayatkan di dalam kitab hadis yang enam, sehingga kedudukannya memang kuat.

Bahkan al-Sabuni menegaskan bahwa hadis-hadis tersebut mencapai batas mutawatir dan bangsa-bangsa muslim amat sadar terhadap larangan tersebut sehingga seni patung dan lukisan makhluk bernyawa tidak

\footnotetext{
${ }^{4}$ Muslim, Sahih Muslim, Beirut: Darul Fikri, 1424, II : 321.

${ }^{5}$ Ibid.
} 
berkembang dikalangan mereka. Para seniman muslim dalam seni rupa mengutamakan penggunaan ukiran geometris dan figur tumbuh-tumbuhan. ${ }^{6}$

Meskipun umumnya hadis-hadis -juga pendapat ulama- mengatakan patung dan lukisan makhluk bernyawa adalah haram, akan tetapi tidak tertutup kemungkinan untuk mengkaji ulang hal tersebut. Oleh karena itu dapat dipertimbangkan hal-hal sebagai berikut:

1. Bahwa masalah ini dapat dikategorikan sebagai masalah hukum yang $m a^{\prime} q u l$ ma'na, yakni masalah yang logika hukumnya dapat dipahami melalui penalaran rasional.

2. Larangan pembuatan patung dan gambar makhluk hidup itu dapat dilihat dalam konteks perjuangan Nabi memberantas ajaran penyembahan berhala dan menegakkan paham tauhid yang murni, di mana jika membuat patung dan gambar itu tidak diberantas akan merusak aqidah baru.

3. Di zaman modern ini, membuat patung dan lukisan makhluk bernyawa bukanlah untuk disembah. Di lain pihak patung dan lukisan mempunyai beberapa manfaat, misalnya untuk pelajaran, pengabadian peristiwa sejarah dan lain-lain. Atas dasar inilah kiranya dapat disimpulkan bahwa sepanjang norma-norma agama Islam diperhatikan dalam seni patung dan lukisan, maka hukumnya adalah mubah (baca: boleh).

Kemudian kedua, yakni seni suara (vokal dan instrumental) merupakan gejala budaya yang universal, dipraktekkan oleh berbagai bangsa. Di masa Nabi sendiri sudah dikenal nyanyi dan permainan musik. Dan ditinjau dari segi asas umum ajaran agama bahwa seni suara termasuk kategori mu'amalat dunyawiyyah yang asasnya adalah:

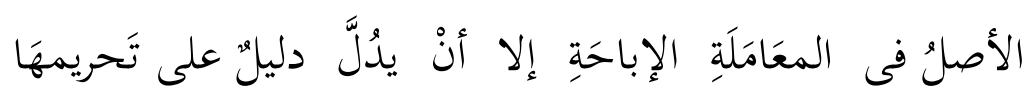

${ }^{6}$ Menurut al-Sabuni bahwa para ulama modern juga mengecualikan fotografi karena disamakan hukumnya dengan lukisan pada kain, dan tidak sama dengan lukisan hasil kecekatan tangan sebab fotofoto hasil pemotretan hanya pengabadian bayangan yang ditangkap kamera dan sangat diperlukan. AlSabuni, Rawa'i al-Bayan, Damaskus: Maktabah al-Ghazali, 1977, hlm. 415- 419. 
“Hukum asal dalam mu'amalah adalah kebolehan sampai ada dalil yang menunjukkan keharamannya" ${ }^{7}$

Semua perbuatan manusia seperti: melihat, mendengar, bergerak, bersuara, menggunakan kaki dan tangan adalah boleh (mubah). Dalam surat Yasin ayat $35^{8}$ dinyatakan bahwa tangan berguna untuk menghasilkan rezeki yang dapat dimakan dan dalam surat al-Balad ayat 8 dan 9,9 dinyatakan bahwa manusia diberi mata, lidah dan bibir yang tentunya bisa digunakan untuk segala kepentingan melihat, berbicara, menyanyi dan sebagainya selama tidak melanggar ketentuan syari'ah.

Atas dasar inilah, maka menyanyi dan memainkan musik pada dasarnya mubah. Larangan baru ada jika dalam menyanyi dan bermusik terjadi pelanggaran norma agama. Larangan timbul karena suatu yang lain, umpamanya dilakukan dengan cara dan tujuan yang tidak dibenarkan agama. ${ }^{10}$

${ }^{7}$ H. A. Djazuli, Kaidah-kaidah Fikih, Jakarta: Kencana Prenada Media Group, 2006, hlm. 10. Lihat Abdul Mudjib, Kaidah-kaidah Ilmu Fiqh, Jakarta: Kalam Mulia, 2005, hlm. 10. Bandingkan dengan Ahmad Sudirman Abbas, Qawa'id Fiqhiyyah dalam Perspektif Fiqih, Jakarta: Anglo Media, 2004, hlm. 68.

8 Ayat tersebut berbunyi:

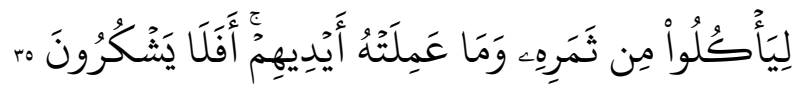

"Supaya mereka dapat makan dari buahnya, dan dari apa yang diusahakan oleh tangan mereka. Maka mengapakah mereka tidak bersyukur?”.

${ }^{9}$ Ayat tersebut berbunyi:

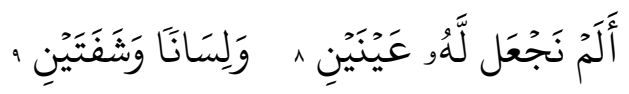

"Bukankah kami Telah memberikan kepadanya dua buah mata, lidah dan dua buah bibir".

10 Ulama yang mengharamkan menyanyi dan bermusik mengemukakan alasan antara lain ialah bahwa musik dan nyanyian itu adalah jenis hiburan, permainan atau kesenangan yang bisa membawa orang lalai dari melakukan kewajiban-kewajibannya, baik terhadap agama, misalnya shalat, lupa studinya dan malas mencari nafkah, maupun terhadap masyarakat dan negara seperti mengabaikan tugas organisasi atau tugas negara. Tampaknya dalil syar'I yang dipakai ulama yang mengharamkan musik dan nyanyian itu adalah yang disebut sadd al-zari'ah, yang artinya mencegah orang berbuat kepada hal-hal yang dilarang oleh agama. Masjfuk Zuhdi, Masail Fiqhiyah; Kapita Selekta Hukum Islam, Jakarta: CV Haji Masagung, 1992, hlm. 96. Lihat juga Nasrun Haroen, Ushul Fiqh, Jakarta: Logos Wacana Ilmu, 1997, I : 160. Bandingkan dengan Amir Syarifuddin, Ushul Fiqh, Jakarta: Logos Wacana Ilmu, 2001, II : 396. 
Dalil-dalil tersebut antara lain, surat Lukman ayat 19 yang berbunyi:

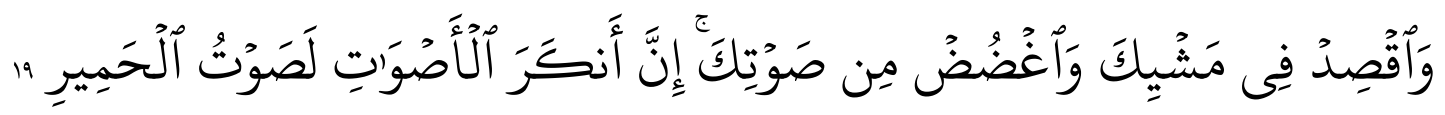

"Dan sederhanalah kamu dalam berjalan dan lunakkanlah suaramu.

Sesungguhnya seburuk-buruk suara ialah suara keledai".

Selanjutnya hadis riwayat Bukhari yang menerangkan bahwa ketika 'Aisyah mengadakan pesta pernikahan untuk seorang wanita dan lelaki Anshor, Nabi menanyakan: "Wahai 'Aisyah apakah kamu tidak punya hiburan?, orang-orang Anshor senang dengan hiburan". ${ }^{11}$ Dan hadis riwayat Bukhari juga di kitab 'Idain yang menerangkan bahwa Rasulullah dan isterinya 'Aisyah menonton permainan tari orang-orang Habasyah dan mendengar nyanyian dayang-dayang pada hari raya. ${ }^{12}$

Dengan dalil tersebut dapat ditarik kesimpulan bahwa nyanyian dan musik sebagai seni yang menghasilkan keindahan adalah mubah atau boleh hukumnya. Memang para ulama berbeda pendapat antara yang memakruhkan, menghalalkan dan mengharamkan mendengar nyanyian dan musik sebaliknya nas justru menunjukkan kebolehannya.

Alasan para ulama yang mengharamkan karena nyanyian dianggap sebagai ucapan yang tidak berguna ${ }^{13}$ atau perbuatan yang tidak bermanfaat. ${ }^{14}$ Sedangkan Yusuf Qardhawi mengatakan bahwa nyanyian dan musik yang

${ }^{11}$ Lihat Bukhari, Sahih al-Bukhari, Beirut: Dar al-Fikr, 1423, III : 253.

12 Ibid., I : 170.

13 (lahw al-hadis) Lihat Q.S Lukman ayat 6. Ayat ini melarang perkataan dan perbuatan tolol berupa caci maki dan cercaan dan tidak tepat mengharamkan nyanyian dan musik.

14 (al-Laghw). Lihat Q.S .al-Qashah ayat 55. 
dilarang adalah yang merangsang, membangkitkan syahwat, menimbulkan fitnah dan menenggelamkan orang dalam maksiat. ${ }^{15}$

Menurut Yusuf Qardhawi ${ }^{16}$ pula bahwa hal-hal yang harus diperhatikan dalam hal nyanyian antara lain:

1. Tidak semua nyanyian hukumnya mubah atau boleh, karena isinya harus sesuai dengan etika islami dan ajaran-ajarannya

2. Penampilan dan gaya menyanyikannya juga perlu dilihat

3. Nyanyian tersebut tidak disertai dengan sesuatu yang haram, seperti minum khamar, menampakkan aurat, atau pergaulan bebas laki-laki dan perempuan tanpa batas.

4. Nyanyian -sebagaimana semua hal yang hukumnya mubah (boleh)- harus dibatasi dengan sikap tidak berlebih-lebihan.

Dengan demikian dari keterangan Qardhawi bahwa seni dalam Islam yaitu sebagai pengejawantahan estetik dan tauhid. Seni itu sifatnya fungsional dan utilitarian namun tidak dalam pengertian terbatas kata-kata yang terkait dalam pandangan eksternal lahiriah mengenai dunia.

Kegunaan seni terkait langsung dengan manusia yang baginya nilai keindahan adalah suatu dimensi kehidupan yang perlu bagi peningkatan harkat dan martabat manusia. Seni tidak berdasarkan pada gagasan seni untuk seni melainkan berdasarkan pada gagasan seni untuk manusia yang dalam konteks Islam; manusia adalah khalifah di muka bumi, mengabdi dan beribadah kepada Tuhan, berarti juga seni demi Tuhan.

Dari segi filsafat hukum Islam, seni setidaknya dapat dikategorikan ke dalam kebutuhan tersier (maslahah tahsiniyyah) yang tujuannya adalah

15 Yusuf Qardhawi, Fatwa-fatwa Kontemporer, edisi Indonesia, Jakarta: Gema Insani Press, 1995, hlm. 867.

${ }^{16}$ Ibid., hlm. 872. 
mewujudkan maslahat. Para pakar hukum Islam mengkategorikan maslahat ke dalam tiga tingkatan: 17

1. Maslahah dharuriyyah, yaitu kepentingan yang harus ada demi kelangsungan hidup manusia, di mana bila kepentingan tersebut tidak terpenuhi, maka kelangsungan hidup terancam.

2. Maslahah hajiyyah, yaitu kepentingan yang harus ada agar hidup manusia menjadi layak dan normal, di mana jika kepentingan itu tidak terwujud, maka hidup manusia tidak terancam namun berada dalam kesulitan dan tidak layak atau normal.

3. Maslahah tahsiniyyah, yaitu kepentingan yang perwujudannya dapat memberi nilai tambah di atas kehidupan yang layak dan normal sehingga hidup manusia menjadi lebih indah, lebih lengkap dan lebih sempurna.

Hukum Islam tidak mengharamkan sesuatu yang betul-betul dibutuhkan oleh manusia dalam realitas kehidupannya. Syari' at Islam sangat memperhitungkan keadaan darurat yang sewaktu-waktu menimpa dan menekan keberadaan manusia. Dan hukum Islam juga memperhatikan fitrah manusia dalam hal kecenderungannya pada bermacam-macam permainan seperti; lomba lari, pacuan kuda dan sejenisnya termasuk juga seni, asalkan tidak diikuti perjudian dan tidak sampai menghalangi dalam ibadah. ${ }^{18}$

Seni sebagai pengejawantahan estetik terhadap ruh tauhid, bukan sesuatu yang mubazir tetapi seni perlu untuk penyempurnaan hidup manusia, peningkatan martabat dan harkat serta penghalusan jiwa dan budi. Seni adalah maslahah yang perwujudannya menjadi tujuan hukum Islam. Jika demikian tujuan seni, maka tidak tertutup kemungkinan kebolehannya.

\footnotetext{
: 4-5.

${ }^{17}$ Lihat Abu Ishaq as-Syatibi, Al-Muwafawat fi Usul asy-Syari'ah, Beirut: Dar al-Ma'arif, t.t, III

${ }^{18}$ Dahlan Tamrin, Filsafat Hukum Islam, Malang: UIN Malang Press, 2007, hlm. 38.
} 


\section{Penutup}

Perjalanan pembentukan hukum Islam sejalan dengan kemaslahatan manusia. Setiap urusan yang di dalamnya mengandung maslahat umum, maka hal itu menjadi tuntutan syari'at. Sebaliknya setiap urusan yang di dalamnya mengandung unsur madarat, maka hal itu menjadi penolakan syari'at. Dan setiap urusan yang mengandung manfaat akan tetapi mafsadatnya lebih banyak, maka hal itu pun menjadi penolakan syari'at.

Adanya pembatasan-pembatasan terhadap seni (baca: seni patung, lukis, gambar, dan suara) karena adanya sikap kehati-hatian dari pakar hukum Islam dan kaum Muslimin. Kehati-hatian itu dimaksudkan agar mereka tidak terjerumus kepada hal-hal yang bertentangan dengan nilai-nilai Islam yang menjadi titik perhatian pada waktu itu. Atas dasar kehati-hatian ini pulalah hendaknya dipahami hadits-hadits yang melarang menggambar atau melukis dan memahat makhluk-makhluk hidup.

Apabila seni membawa manfaat bagi manusia, memperindah hidup dan hiasannya yang dibenarkan agama, mengabadikan nilai-nilai luhur dan menyucikannya, serta mengembangkan serta memperhalus rasa keindahan dalam jiwa manusia, maka sunnah Nabi mendukung, tidak menentangnya. Namun jika pekerjaan tersebut mengandung maksiat, perbuatan dosa atau yang membawa kepada yang demikian, maka perbuatan tersebut jelas dilarang. 


\section{DAFTAR PUSTAKA}

.Abbas, Ahmad Sudirman, Qawa'id Fiqhiyyah dalam Perspektif Fiqih, Anglo Media, Jakarta, 2004.

Alwi, Hasan, dkk., Kamus Besar Bahasa Indonesia, Balai Pustaka, Jakarta, 2005.

As-Syatibi, Abu Ishaq, Al-Muwafawat fi Usul asy-Syari'ah, Dar al-Ma'arif, Beirut, t.t.

Bukhari, Sahih al-Bukhari, Dar al-Fikr, Beirut, 1423.

Djazuli, H. A., Kaidah-kaidah Fikih, Kencana Prenada Media Group, Jakarta, 2006.

Faruqi, Al-, The Cultural Atlas of Islam, Macmilland Publishing Company, New York, 1986.

Haroen, Nasrun, Ushul Figh, Logos Wacana Ilmu, Jakarta, 1997.

Mudjib, Abdul, Kaidah-kaidah Ilmu Fiqh, Kalam Mulia, Jakarta, 2005.

Muslim, Sahih Muslim, Darul Fikri, Beirut, 1424.

Qardhawi, Yusuf, Fatwa-fatwa Kontemporer, edisi Indonesia, Gema Insani Press, Jakarta, 1995.

Sabuni, Al-, Rawa'i al-Bayan, Maktabah al-Ghazali, Damaskus, 1977.

Syarifuddin, Amir, Ushul Figh, Logos Wacana Ilmu, Jakarta, 2001.

Tamrin, Dahlan, Filsafat Hukum Islam, UIN Malang Press, Malang, 2007.

Zuhdi, Masjfuk, Masail Fiqhiyah; Kapita Selekta Hukum Islam, CV Haji Masagung, Jakarta, 1992. 